\title{
Diagnostic Accuracy for Malignancy in Open Surgical Biopsy of Neck Lymph Nodes
}

\author{
Gwanghui Ryu', Jae-Keun Cho², and Han-Sin Jeong ${ }^{1}$ \\ ${ }^{1}$ Department of Otorhinolaryngology-Head and Neck Surgery, Samsung Medical Center, Sungkyunkwan University School of Medicine, \\ Seoul; and ${ }^{2}$ Department of Otolaryngology-Head and Neck Surgery, Pusan National University Hospital, Busan, Korea
}

\section{경부 림프절 절제 생검의 진단 정확도 분석}

류광희 ${ }^{1} \cdot$ 조재근 $^{2} \cdot$ 정한신 $^{1}$

성균관대학교 의과대학 삼성서울병원 이비인후-두경부외과학교실, ${ }^{1}$ 부산대학교병원 이비인후과 ${ }^{2}$

\author{
Received June 13, 2014 \\ Revised July 18, 2014 \\ Accepted August 11, 2014 \\ Address for correspondence \\ Han-Sin Jeong, MD, PhD \\ Department of Otorhinolaryngology- \\ Head and Neck Surgery, \\ Samsung Medical Center, \\ Sungkyunkwan University \\ School of Medicine, \\ 81 Irwon-ro, Gangnam-gu, \\ Seoul 135-710, Korea \\ Tel +82-2-3410-3579 \\ Fax +82-2-3410-3879 \\ E-mail hansin.jeong@gmail.com
}

Background and Objectives The open surgical biopsy (OSB) of neck lymph nodes is considered a definite diagnostic procedure; however, the diagnostic accuracy of this procedure has not been fully studied. Thus, we aimed to identify the false negative rates of OSB for malignancy and the possible causes of misdiagnosis that might severely affect patient prognosis.

Subjects and Method We extracted the data from 495 OSB of neck lymph nodes between 2005 and 2012. The diagnostic accuracy of OSB of neck lymph nodes was estimated based on rebiopsy. In addition, we reviewed possible clinical factors related to false negativity, cause of misdiagnosis and its clinical impacts.

Results The false negative rate of OSB of neck nodes was $2.2 \%$ with a risk of $3.8 \%$ false diagnosis among subjects with initial 'benign' results. The cases of the initial misdiagnosis $(n=7)$ had the dismal outcomes ( 4 deaths, 1 disease progression). The main cause of misdiagnosis was the failure to target the disease-affected lymph nodes $(85.7 \%)$. Malignancy-related symptoms persisted in all cases of misdiagnosis, which required re-biopsy.

Conclusion Accurate targeting of lymph nodes, close monitoring of clinical symptoms and comparison of biopsy results with symptoms are very important to reduce false negativity for malignancy in OSB of neck lymph nodes.

Korean J Otorhinolaryngol-Head Neck Surg 2014;57(12):841-6

Key Words Biopsy - Diagnosis - False negative reactions - Lymph nodes · Neoplasm.

\section{서 론}

경부 림프절 비대는 이비인후과를 내원하는 환자의 흔한 증 상으로 원인 진단을 위하여 자세한 병력 청취, 신체 진찰, 혈액 검사 또는 영상학적 검사를 우선적으로 시행한다. ${ }^{1,2}$ 경부 종 물에 대한 직접적 원인 진단법으로는 세침 흡인 검사(fine needle aspiration cytology)가 표준적인 검사로 알려져 있지만, ${ }^{3,4}$ 정확한 진단을 얻지 못하는 경우도 흔히 있다. 예를 들면, 진 단에 필요한 세포가 흡인되지 않았거나 그 양이 충분하지 않 은 경우 등이 있을 수 있으며, ${ }^{5-7)}$ 이러한 경우 반복적인 세침 흡
인 검사가 필요하다.

세침 흡인 검사에서 정확한 진단을 얻지 못한 경우, 중심부 바늘 생검(core needle biopsy) 또는 절개 및 절제 생검을 시 행하게 된다. ${ }^{1)}$ 중심부 바늘 생검은 두경부 종양에서 $87 \%$ 의 진단 정확도를 나타내는 것으로 보고되었다. ${ }^{8)}$ 그런데, 악성 림프종 환자에서 세침 흡인 검사와 중심부 바늘 생검은 $90 \%$ 의 진단율을 보이지만, 림프종 아형 분류는 $75 \%$ 의 환자에서 만 가능하였다는 연구 결과가 있다. ${ }^{9}$ 즉, 잠정적인 병리 진단을 얻은 경우라 할지라도, 조직병리학적 확진, 아형의 확인을 위 하여 절제 또는 절개 생검이 필요한 경우가 있으며, 생검의 결 
과는 악성 종양 및 여러 양성 질환의 진단에 있어 결정적인 역 할을 하게 된다.

림프절 절제 생검은 가장 명확한 진단법으로 고려되지만, 절제 생검 역시 술기의 문제, 대표적 림프절을 선택하지 못한 경우, 병리 판독이 잘못된 경우 등의 이유로 오진의 가능성이 있을 수 있다. ${ }^{10)}$ 한 연구에 의하면, 림프종 환자에서 절제 생검 의 위음성률은 $21 \%$ 이며 위음성률을 낮추기 위해 병변이 있는 대표성 있는 림프절을 정확히 찾을 수 있도록 초음파를 이용 하여 절제 생검 할 것을 권고하고 있다. ${ }^{10)}$ 하지만 악성 림프종 환자 이외의 다양한 악성 종양을 대상으로 림프절 절제 생검 의 진단 정확도, 위음성률, 위음성에 영향을 미치는 요인 등에 대한 연구는 수행된 바가 없는 실정이다. 만일, 절제 생검에서 오진이 되는 경우 환자의 예후에 중대한 영향을 미칠 수 있기 때문에 절제 생검의 진단 정확도에 대한 연구는 매우 중요한 임상적 의의를 갖는다고 생각된다. 이에 본 연구에서는 악성 종양에 대한 절제 생검의 위음성률을 파악하고 위음성의 원 인을 분석하여 그에 따른 임상적 영향을 파악하고자 하였다.

\section{대상 및 방법}

\section{대상 환자의 선택}

2005년부터 2012년까지 경부 림프절 절개 또는 절제 생검 을 받은 환자들을 대상으로 후향적 의무기록 분석을 시행하 였다. 8년의 기간 동안 이비인후과에서 495명의 환자가 경부 림 프절 생검을 받았다. 같은 연구 기간 동안 경부 림프절 비대를 주소로 내원하여 세침 흡인 검사를 받은 환자는 7500 명이며 이 중 5300 명은 초음파 유도 하 세침 흡인 검사를 받았다.

경부 림프절 생검은 림프계 악성이 강력하게 의심되거나 조직학적 세부 분류의 확인이 필요한 경우에 시행되었다. 대 부분의 절제 생검 대상 환자들은 한 번 이상의 세침 흡인 검 사를 받았으나 진단이 되지 않은 경우였다. 림프절이 표층에 존재하여 아주 쉽게 촉진되는 경우를 제외하고 모든 환자에 서 수술 전 컴퓨터단층촬영(computed tomography, CT) 또는 초음파 검사를 시행하였다. 만일, 영상학적 검사나 임상 소견 으로 림프계 종양이 아주 강력히 의심되는 경우에는 세침 흡인 검사를 시행하지 않고 바로 림프절 생검을 진행하였다. 일부 환자에서는 초음파 유도 하 중심부 바늘 생검을 시행하였는 데, 검사 결과 종양 세부 분류 진단이 가능한 경우에는 절제 생검을 시행하지 않았다.

환자의 나이, 성별, 생검 위치, 병리 결과, 추정 진단 및 확정 진단, 임상적 경과에 대한 의무기록 분석을 하였다. 조직 생검 에서 양성 소견을 보인 환자들은 대부분 생검 후 3 6개월 정 도 추적관찰을 하였고, 악성 질환으로 진단된 경우 적절한 평
가 및 치료가 이루어졌다. 본 후향적 연구는 연구 시작 이전에 기관윤리심의위원회의 승인(File No. 2013-07-114)을 받았 으며 동의서는 면제되었다.

\section{위음성의 정의}

본 연구에서 림프절 절제 생검이라 함은 림프절을 채취하는 술기와 더불어 채취된 림프절의 병리 검사까지의 모든 과정을 의미하는 것으로 정의하였고, 임상적으로 환자의 질병을 진단 하는 정확도를 확인하고자 하였다.

절제 생검의 위음성은 다음과 같이 정의하였다. 1) 처음 시 행한 절제 생검에서 양성 질환으로 진단되었으나, 2) 발열, 체 중 감소, 전신 쇠약감 등 악성 질환과 연관된 임상적 증상이 지속되며, 3) 12 개월 이내에 재시행한 조직 생검(림프절 생검 또는 골수 등 다른 부위의 조직 생검)에서 악성 종양으로 진단 된 경우로 규정하였다. 각 위음성 환자에 대해서 $\mathrm{CT}$, 초음파, 양전자방출단층촬영(PET-CT) 검사 등 2 가지 이상의 영상 검 사를 포함하여 임상적 경과를 면밀하게 검토하여, 1 차 생검 후 새로 발병된 악성 종양의 가능성을 배제하였다.

상기 정의한 위음성 기준에 따라 495 명의 환자 중 7 명의 환 자가 위음성으로 파악되었다. 7명의 환자 모두 처음 조직 생검 을 시행하기 전 촬영한 영상학적 검사에서 악성 질환이 의심되 는 소견이었다. 조직 생검의 병리 결과는 반응성 림프절 비대, 만성 육아종성 염증, 림프절 괴사 소견이었으며 림프 조직이 없다는 병리 보고도 있었다. 처음 시행한 절제 생검과 최종 진 단시 시행한 조직 생검 사이 기간은 평균 3개월 15일(3일 12개 월)이었다.

\section{자료 분석}

자료를 통하여 위음성률을 산출하여 오진의 원인을 파악하 였고, 각 환자의 특성, 영상학적 검사 결과, 병리 결과, 수술 기 록을 분석하였다. 또한 위음성 환자군과 진음성(true negative) 환자군의 특성을 비교하여 오진에 영향을 미치는 요인을 파 악하였다. 위음성 환자의 임상 경과를 분석하여 오진이 환자 에게 미치는 임상적 영향을 평가하였다.

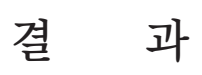

\section{경부 림프절 절제 생검의 진단 정확도}

495명의 절제 생검 결과 악성 질환 진단의 민감도는 $97.8 \%$, 특이도는 $100 \%$ 였다(Fig. 1). 310 명의 진양성(true positive) 환 자의 병리 진단은 Table 1 에 요약하였으며, 위음성률(=첫 번째 절제 생검 결과가 양성인 환자 수/악성 종양으로 진단된 모든 환자수 $=7 / 317)$ 은 $2.2 \%$ 이며 음성예측도는 $96.2 \%$ 였다. 결국 절 


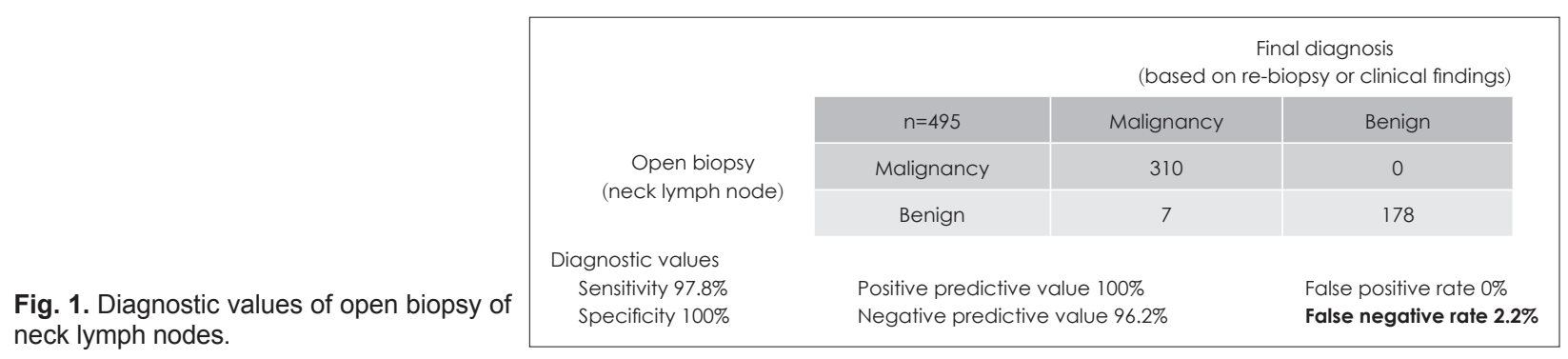

Table 1. Pathologic diagnosis of true positive cases

\begin{tabular}{|c|c|c|}
\hline Pathology diagnosis (total $n=310$ ) & No. & $\%$ \\
\hline Lymphoid malignancy & 231 & 74.5 \\
\hline Diffuse large B-cell lymphoma & 82 & 26.5 \\
\hline Hodgkin's lymphoma & 40 & 12.9 \\
\hline Follicular lymphoma & 24 & 7.7 \\
\hline Angioimmunoblastic T-cell lymphoma & 13 & 4.2 \\
\hline Low grade B-cell lymphoma & 10 & 3.2 \\
\hline Mantle cell lymphoma & 8 & 2.6 \\
\hline Marginal zone B-cell lymphoma & 8 & 2.6 \\
\hline Peripheral T-cell lymphoma & 7 & 2.3 \\
\hline Low grade T-cell lymphoma & 7 & 2.3 \\
\hline Anaplastic large cell lymphoma & 4 & 1.3 \\
\hline Burkitt's lymphoma & 3 & 1.0 \\
\hline Non-Hodgkin's lymphoma & 3 & 1.0 \\
\hline NK/T-cell lymphoma & 2 & 0.6 \\
\hline Malignant lymphoma, subtype-unknown & 20 & 6.5 \\
\hline Carcinomas* & 68 & 21.9 \\
\hline Metastatic adenocarcinoma & 28 & 9.0 \\
\hline Metastatic carcinoma, subtype-unknown & 25 & 8.1 \\
\hline Metastatic squamous cell carcinoma & 11 & 3.5 \\
\hline Metastatic papillary carcinoma & 4 & 1.3 \\
\hline Others & 11 & 3.5 \\
\hline Multiple myeloma & 3 & 1.0 \\
\hline Sarcoma & 2 & 0.6 \\
\hline Neuroectodermal origin cancer & 2 & 0.6 \\
\hline Malignant melanoma & 1 & 0.3 \\
\hline Germ cell tumor & 1 & 0.3 \\
\hline Thymoma & 1 & 0.3 \\
\hline
\end{tabular}

* primary tumors outside head and neck area $=30$, primary tumors within head and neck area $=28$, metastasis of unknown primary $=10$

제 생검에서 양성으로 진단된 환자(n=185) 중에서 오진 될 확 률은 $3.8 \%(\mathrm{n}=7)$ 였다.

\section{위음성 환자에 대한 사례 분석}

7명의 위음성 환자에 대한 임상적 경과를 상세히 분석하였 다(Table 2). 특징적인 2명의 환자의 사례를 살펴보면(Fig. 2), 각 환자는 첫 번째 조직 생검에서 양성으로 진단받은 후 각
각 12 개월, 8 개월 뒤에 재생검으로 악성 종양 진단을 받았다. 첫 번째 환자(No. 1 in Table 2)는 1차 생검 후 림프절 결핵으 로 추정되어, 항결핵약제 치료를 받았으나 임상 경과 및 2 번 의 CT 촬영에서 림프절 비대가 진행한 소견이었다. 결국 림프 절 절제 생검을 다시 시행하였고 검사 결과 편평 세포 암종으 로 진단되었고, 원발 병소는 혀 기저부에서 발견되었다. 두 번 째 환자(No. 4 in Table 2)는 첫 번째 절제 생검에서 양성으 로 진단되었으나 B 증상(발열, 야간 발한, 체중 감소)이 지속 되었다. 재검을 권유하였으나 환자는 수술 흥터 때문에 절제 생검을 거부하였고 결국 8개월 뒤 골수 생검에서 T세포 림프 종으로 진단되었다. 하지만 환자는 질환의 악화로 골수 생검 바로 다음날 사망하였다.

첫 번째 생검에서 오진된 7명의 환자의 임상 경과를 살펴보 면, 4 명은 사망하였고 1 명은 질병이 악화되었다. 이러한 결과 는 환자의 진단이 지연되어서 발생한 것인지 확신할 수는 없지 만, 질병의 초기 단계에 적절한 치료를 받지 못한 것이 영향을 미친 것으로 판단되었다. 특히 혀 기저부 편평 세포암으로 진 단된 환자의 경우 적절한 치료를 받지 못한 기간 동안 경부 림 프절 전이는 동측에서 양측으로 진행하여서, 양측 림프절에 대한 치료가 필요하였다.

7명의 환자에서 오진의 가장 주요한 원인은 질병에 이환된 림프절에 대한 선택이 잘못되었음(85.7\%)을 확인할 수 있었다.

\section{위음성과 관련된 요인 분석}

오진에 영향을 미치는 기여 요인을 알아내기 위해 첫 번째 검 사시 양성으로 진단된 185 명의 환자에 대해 분석하였다. 환자 들의 특성은 Table 3에 정리하였으며, 가장 많은 진단은 $37.6 \%$ 의 육아종성 질환(결핵, 비특이적 육아종성 질환, 사르코이드 증)이었다. 위음성 환자군과 진음성 환자군에 대하여 단변량 및 다변량 분석을 시행하였고, 그 결과 성별(남성)이 유일하 게 의미있는 요인이었다(Table 4). 흥미롭게도, 절제한 림프절 의 특성(크기, 다발성, 위치)과 수술의 기술적 요인(마취의 종 류, 방법, 술자의 경험)은 위음성 여부와 관련이 없었다. 


\section{고 찰}

경부 림프절 절제 생검은 비교적 정확하여 확실한 진단법
으로 여겨지지만, 이에 대한 진단정확도 연구는 거의 이루어 지지 않았다. 본 연구를 통하여 절제 생검의 오진율(위음성 률 2.2\%)을 추정할 수 있었고, 절제 생검의 진단 오류 가능성

Table 2. Characteristics of false negative cases on open surgical biopsy of neck lymph nodes

\begin{tabular}{|c|c|c|c|c|c|c|c|c|c|}
\hline \multirow{2}{*}{ No. } & \multirow{2}{*}{ Gender } & \multirow{2}{*}{ Age } & \multirow{2}{*}{$\begin{array}{l}\text { Initial } \\
\text { symptoms }\end{array}$} & \multicolumn{2}{|c|}{ Pathology results } & \multirow{2}{*}{ Duration } & \multirow{2}{*}{$\begin{array}{c}\text { Final } \\
\text { diagnosis }\end{array}$} & \multirow{2}{*}{$\begin{array}{l}\text { Clinical } \\
\text { course }\end{array}$} & \multirow{2}{*}{$\begin{array}{l}\text { Possible cause } \\
\text { of false negativity }\end{array}$} \\
\hline & & & & 1st biopsy & 2nd biopsy & & & & \\
\hline 1 & M & 57 & Neck mass & Tb lymphadenitis & $\begin{array}{l}\text { Metastatic } \\
\text { squamous cell } \\
\text { carcinoma }\end{array}$ & $12 \mathrm{mo}$ & $\begin{array}{l}\text { Left base of } \\
\text { tongue } \\
\text { cancer with } \\
\text { metastasis }\end{array}$ & $\begin{array}{l}\text { NED } \\
\text { (8 mo) }\end{array}$ & $\begin{array}{l}\text { Targeting error } \\
\text { for representative } \\
\text { lymph nodes }\end{array}$ \\
\hline 2 & M & 47 & Neck mass & Tb lymphadenitis & $\begin{array}{l}\text { Peripheral } \\
\text { T-cell lymphoma }\end{array}$ & $1.5 \mathrm{mo}$ & $\begin{array}{l}\text { Peripheral } \\
\text { T-cell } \\
\text { lymphoma }\end{array}$ & $\begin{array}{l}\text { Expire } \\
\quad(5 \mathrm{mo})\end{array}$ & $\begin{array}{l}\text { Targeting error } \\
\text { for representative } \\
\text { lymph nodes }\end{array}$ \\
\hline 3 & M & 64 & $\begin{array}{l}\text { Infra-auricular } \\
\text { mass }\end{array}$ & $\begin{array}{l}\text { No lymphoid } \\
\text { tissue included }\end{array}$ & $\begin{array}{l}\text { Metastatic } \\
\text { adenocarcinoma }\end{array}$ & $1 \mathrm{mo}$ & $\begin{array}{l}\text { Right parotid } \\
\text { cancer with } \\
\text { metastasis }\end{array}$ & $\begin{array}{l}\text { Expire } \\
\quad(6 \mathrm{mo})\end{array}$ & $\begin{array}{l}\text { Targeting error } \\
\text { for representative } \\
\text { lymph nodes }\end{array}$ \\
\hline 4 & $\mathrm{~F}$ & 26 & Fever & $\begin{array}{l}\text { Reactive } \\
\text { lymphadeno- } \\
\text { pathy }\end{array}$ & $\begin{array}{l}\text { Hemophagocytic } \\
\text { histiocytosis } \\
\text { (bone marrow } \\
\text { biopsy) }\end{array}$ & $8 \mathrm{mo}$ & $\begin{array}{l}\text { T-cell } \\
\text { lymphoma }\end{array}$ & $\begin{array}{l}\text { Expire } \\
\text { (1 day) }\end{array}$ & $\begin{array}{l}\text { Targeting error } \\
\text { for representative } \\
\text { lymph nodes }\end{array}$ \\
\hline 5 & M & 82 & Neck mass & $\begin{array}{l}\text { A lymph node } \\
\text { with infarction }\end{array}$ & $\begin{array}{l}\text { Non-small cell } \\
\text { lung cancer } \\
\text { (chest CT \& } \\
\text { biopsy) }\end{array}$ & 3 day & $\begin{array}{l}\text { Lung cancer } \\
\text { with } \\
\text { metastasis }\end{array}$ & $\begin{array}{l}\text { Expire } \\
\quad(1 \mathrm{mo})\end{array}$ & $\begin{array}{l}\text { Targeting error } \\
\text { for representative } \\
\text { lymph nodes }\end{array}$ \\
\hline 6 & M & 34 & Neck mass & $\begin{array}{l}\text { Mainly adipose } \\
\text { tissue }\end{array}$ & B-cell lymphoma & $1 \mathrm{mo}$ & $\begin{array}{l}\text { B-cell } \\
\text { lymphoma }\end{array}$ & $\begin{array}{l}\text { NED } \\
\text { (14 mo) }\end{array}$ & $\begin{array}{l}\text { Targeting error } \\
\text { for representative } \\
\text { lymph nodes }\end{array}$ \\
\hline 7 & M & 72 & Neck mass & $\begin{array}{l}\text { Ghost of } \\
\text { necrotic } \\
\text { B-lymphocytes }\end{array}$ & B-cell lymphoma & $1 \mathrm{mo}$ & $\begin{array}{l}\text { B-cell } \\
\text { Iymphoma }\end{array}$ & $\begin{array}{l}\text { NED } \\
\quad(48 \mathrm{mo})\end{array}$ & $\begin{array}{l}\text { Misinterpretation } \\
\text { of pathology }\end{array}$ \\
\hline
\end{tabular}

Tb: tuberculosis, NED: no evidence of disease

1st biopsy

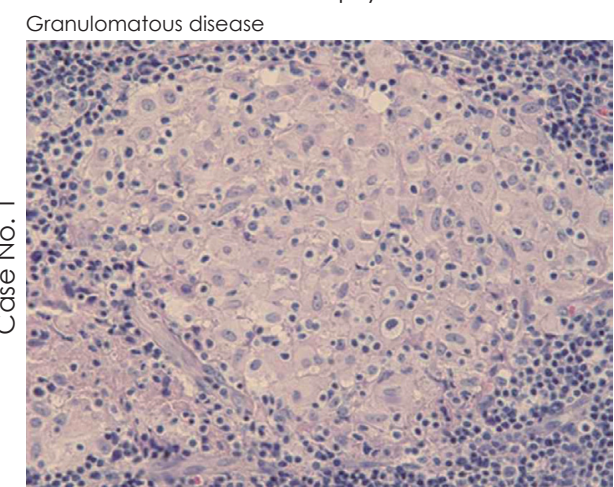

No lymphoid tissue

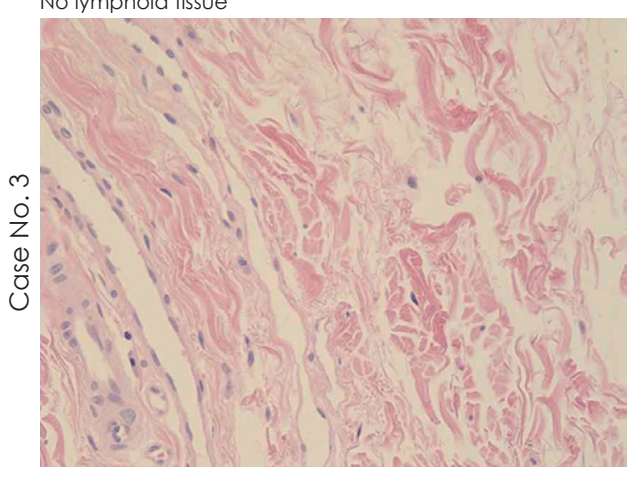

2nd biopsy

Squamous cell carcinoma

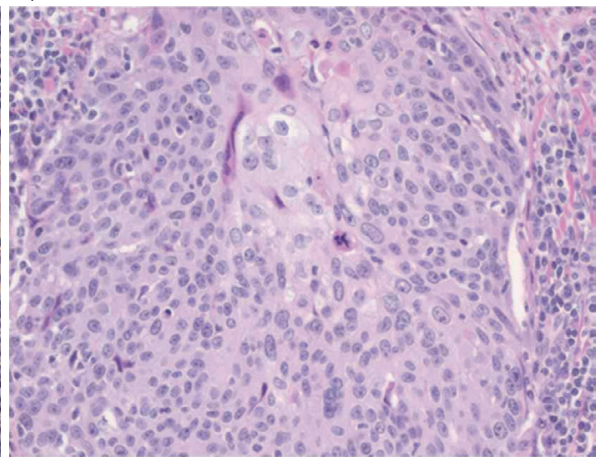

Adenocarinoma

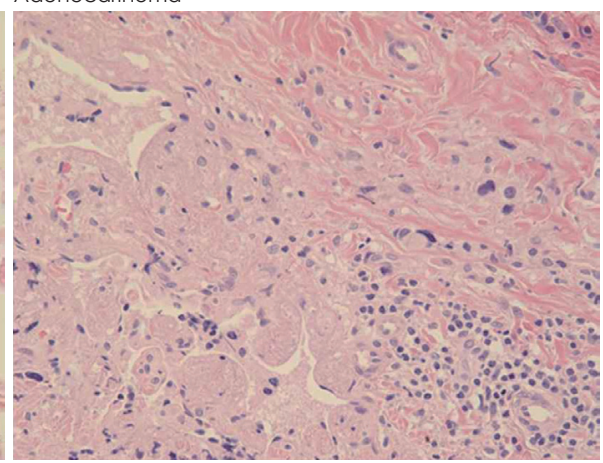

Fig. 2. Representative images of false diagnosis in open surgical biopsy. 
을 알리고자 하였다. 특히, 위음성 환자는 치명적인 질병의 악 화(70\%)를 보였고, 이와 같은 결과가 진단의 지연에 의해 발생 한 것인지 확실하게 알 수는 없지만, 적절한 진단이 지연되어 치료의 시작이 늦어지는 결과를 초래하였다.

본 연구는 8 년의 기간 동안 비교적 많은 환자수(495명)를 분
석하였으며, 위음성을 명확히 정의하기 위하여 여러 기준을 사 용하였다. 즉, 첫 번째 조직 생검 후 최종 진단까지의 기간 동 안 새로 발병한 질환일 가능성이 있는 환자는 엄격히 배제하 였다. 그러기 위해서 지속적인 림프절 비대 또는 지속적인 악 성 관련 증상이 있는 경우만을 위음성군에 포함시켰다. 따라

Table 3. Subject characteristics of true negative cases

\begin{tabular}{|c|c|}
\hline True negative cases & $n=178$ \\
\hline Gender (M:F, No. [\%]) & $73: 105[41.0: 59.0]$ \\
\hline Age (mean, [range]) & $45[5-80]$ \\
\hline \multicolumn{2}{|l|}{ Lymphadenopathy } \\
\hline Multiplicity (multiple:single, No. [\%]) & $148: 30[83.1: 16.9]$ \\
\hline Neck side (bilateral:unilateral, No. [\%]) & $83: 95[46.6: 53.4]$ \\
\hline Lymph node level for biopsy (level I/II/III/IV/V, No. [\%]) & $17 / 38 / 31 / 28 / 64[9.6 / 21.3 / 17.4 / 15.7 / 36.0]$ \\
\hline Size of lymph node biopsied (max diameter, mean \pm SD) & $1.6 \pm 0.9 \mathrm{~cm}$ \\
\hline \multicolumn{2}{|l|}{ Pre-biopsy imaging work-ups* (No. [\%]) } \\
\hline Neck CT & $155[87.1]$ \\
\hline Ultrasonography & $7[3.9]$ \\
\hline PET $(C T)$ & $7[3.9]$ \\
\hline Chest CT & $2[1.1]$ \\
\hline None & 7 [3.9] \\
\hline \multicolumn{2}{|l|}{ Pathology diagnosis (No. [\%]) } \\
\hline Reactive lymphadenopathy & $47[26.4]$ \\
\hline Tuberculosis lymphadenitis & $37[20.8]$ \\
\hline Granulomatous lymphadenitis & 29 [16.3] \\
\hline Kikuchi disease & $13[7.3]$ \\
\hline Necrotizing lymphadenitis & $11[6.2]$ \\
\hline Lymph node hyperplasia & $7[3.9]$ \\
\hline Castleman's disease & $4[2.2]$ \\
\hline Toxoplasma lymphadenitis & $4[2.2]$ \\
\hline EBV lymphadenitis & $3[1.7]$ \\
\hline Progressive transformation of germinal center & $3[1.7]$ \\
\hline Sarcoidosis & $1[0.6]$ \\
\hline No lymphoid tissue included & $2[1.1]$ \\
\hline Others $^{\dagger}$ & $17[9.6]$ \\
\hline
\end{tabular}

*pre-biopsy imaging work-ups: did not include the ultrasonography-guided fine needle aspiration for lymphadenopathy, performed as an initial work-up, tothers: lipoma, pilomatrichoma, schwannoma, Warthin's tumor, lupus, xanthoma, fibrosis, etc. PET: positron emission tomography, EBV: Ebstein-Barr virus

Table 4. Analysis of clinical factors related to the false negativity of open surgical biopsy of neck lymph nodes

\begin{tabular}{|c|c|c|c|}
\hline \multirow{2}{*}{ Variable } & \multirow{2}{*}{ Univariate analysis ( $p$-value) } & \multicolumn{2}{|c|}{ Multi-variable analysis ${ }^{\dagger}$} \\
\hline & & OR $[95 \% \mathrm{Cl}]$ & $p$-value \\
\hline Age (continuous) & $0.21^{*}$ & $1.02[0.98-1.06]$ & 0.26 \\
\hline Gender (M vs. F) & $0.04^{\dagger}$ (for male preponderance) & $8.48[1.82-39.42]$ & 0.006 \\
\hline Size of biopsied lymph node (continuous) & $0.23^{*}$ & $0.93[0.49-1.77]$ & 0.82 \\
\hline Neck level (I, II, III, IV, V) & $0.78^{\dagger}$ & $0.98[0.58-1.65]$ & 0.93 \\
\hline Multiplicity (single vs. multiple) & $0.60^{\dagger}$ & $6.70[0.50-89.66]$ & 0.15 \\
\hline Side (ipsilateral vs. bilateral) & $0.46^{\dagger}$ & $0.32[0.07-1.44]$ & 0.14 \\
\hline Anesthesia (local vs. general) & $0.42^{\dagger}$ & $0.56[0.11-2.82]$ & 0.48 \\
\hline Method of biopsy (excision vs. incision) & $0.47^{\dagger}$ & $0.86[0.10-7.44]$ & 0.89 \\
\hline Operator (trainee vs. staff) & $0.72^{\dagger}$ & $2.02[0.41-10.08]$ & 0.39 \\
\hline
\end{tabular}

*Mann-Whitney test, tFisher's exact test, flogistic regression using Firth's penalized maximum likelihood estimator with odds ratio estimates and Wald confidence intervals. Goodness of fit index by Hosmer-Lemeshow test $p=0.2246$, c-statistics $=0.857$ 
서 이러한 기준 때문에, 실제 경부 림프절 절제 생검의 위음 성률보다 과소 평가되었을 가능성이 있으며, 본 연구 결과인 $2.2 \%$ 의 위음성률보다 실제로는 더 높을 수 있을 것으로 판단 된다.

위음성에 영향을 미치는 요인 분석에서 남성이 주요한 위험 요인으로 확인되었다. 이것은 경부 림프절 비대를 보이는 양성 질환이 남성보다 여성에서 더 빈번하기 때문일 것으로 추정 된다. ${ }^{11,12)}$ 또한, 일반적으로 남성에서 악성 질환의 빈도가 높은 점, 성별 차이에 의한 체형의 차이 등이 또 다른 원인으로 생각 된다.

반면, 절제된 림프절의 특성이나 수술적 술기는 위음성 발 생과 큰 연관성이 없었다. 하지만, 본 분석에서 위음성의 증례 수가 적어서 $(\mathrm{n}=7)$ 연관 요인의 효과가 명확하게 드러나지 않 았을 가능성을 염두에 두어야 할 것으로 생각된다.

위음성의 가장 주요한 원인은 이전 연구에서 발표된 것과 같이 질병에 이환된 림프절에 대한 적절한 선택이 잘못된 것 이었다. ${ }^{10)}$ 대부분의 환자들은 절제 생검 한 달 이내에 CT와 같 은 영상학적 검사를 시행하였음에도 불구하고, 수술시 잘못 된 림프절을 선택하거나, 영상에서 보이는 림프절의 위치와 수술 자세에서의 위치가 다른 경우 등이 있을 수 있을 것이 다. 그러므로 영상검사를 주의 깊게 검토하여 대표성 있는 림 프절을 정확히 선택하는 것이 위음성을 줄일 수 있는 방법이 며, 표적 림프절에 대해 수술 전 초음파 유도 하에 피부에 위 치를 표시하거나 수술 중에 초음파를 이용하여 표적 림프절 을 확인하는 것도 유용한 방법으로 생각된다.

또 하나 주목해야 할 점은 육아종성 병변과의 감별이다. 분 석 결과를 보면 양성 진단 중 육아종성 병변의 유병률이 높았 고, 악성 질환과 혼재되어 있는 경우 림프절 선택시 오류를 초 래할 수 있을 것으로 보인다. ${ }^{12-14)}$ 특히 육아종과 악성 종양이 혼재되어 있는 경우에는, 육아종에 의하여 악성 종양의 진단 이 늦어져 치료 결과 및 예후가 나빠질 수 있음을 염두에 두 어야 한다.

따라서, 이 경우, 한 개의 림프절보다는 여러 개의 림프절을 절제 생검하는 것이 좋은 해결책이 될 수 있을 것으로 생각된 다. 더 중요한 것은 생검 결과를 바탕으로 환자의 임상적 경과 를 주의깊게 추적 관찰하는 것이다. 본 연구에서 위음성 환 자들은 모두 악성 질환과 관련된 증상이나 징후가 지속되었 다. 이러한 경우에는 정확한 진단을 위해 즉각적인 재평가 및
재생검을 시행하여야만 한다.

\section{REFERENCES}

1) Jeong WJ, Park MW, Park SJ, Ahn SH. Initial work-up for cervical lymphadenopathy: back to basics. Eur Arch Otorhinolaryngol 2012; 269(10):2255-63.

2) Atula TS, Varpula MJ, Kurki TJ, Klemi PJ, Grénman R. Assessment of cervical lymph node status in head and neck cancer patients: palpation, computed tomography and low field magnetic resonance imaging compared with ultrasound-guided fine-needle aspiration cytology. Eur J Radiol 1997;25(2):152-61.

3) Schwarz R, Chan NH, MacFarlane JK. Fine needle aspiration cytology in the evaluation of head and neck masses. Am J Surg 1990;159(5): 482-5.

4) Chiu-Lung Chan R, Chan JY. Effect of previous radiotherapy on cervical lymph node fine-needle aspiration cytology diagnostic accuracy in head and neck cancers. Laryngoscope 2012;122(8): 1779-81.

5) Baier ND, Hahn PF, Gervais DA, Samir A, Halpern EF, Mueller PR, et al. Fine-needle aspiration biopsy of thyroid nodules: experience in a cohort of 944 patients. AJR Am J Roentgenol 2009;193(4):1175-9.

6) Yang J, Schnadig V, Logrono R, Wasserman PG. Fine-needle aspiration of thyroid nodules: a study of 4703 patients with histologic and clinical correlations. Cancer 2007;111(5):306-15.

7) Oz A, Demirkazik FB, Akpinar MG, Soygur I, Baykal A, Onder SC, et al. Efficiency of ultrasound and ultrasound-guided fine needle aspiration cytology in preoperative assessment of axillary lymph node metastases in breast cancer. J Breast Cancer 2012;15(2):211-7.

8) Novoa E, Gürtler N, Arnoux A, Kraft M. Role of ultrasound-guided core-needle biopsy in the assessment of head and neck lesions: a meta-analysis and systematic review of the literature. Head Neck 2012;34(10):1497-503.

9) Amador-Ortiz C, Chen L, Hassan A, Frater JL, Burack R, Nguyen TT, et al. Combined core needle biopsy and fine-needle aspiration with ancillary studies correlate highly with traditional techniques in the diagnosis of nodal-based lymphoma. Am J Clin Pathol 2011; 135(4):516-24.

10) Picardi M, Gennarelli N, Ciancia R, De Renzo A, Gargiulo G, Ciancia $\mathrm{G}$, et al. Randomized comparison of power Doppler ultrasounddirected excisional biopsy with standard excisional biopsy for the characterization of lymphadenopathies in patients with suspected lymphoma. J Clin Oncol 2004;22(18):3733-40.

11) Mrówka-Kata K, Kata D, Kyrcz-Krzemień S, Helbig G. KikuchiFujimoto and Kimura diseases: the selected, rare causes of neck lymphadenopathy. Eur Arch Otorhinolaryngol 2010;267(1):5-11.

12) Song JY, Cheong HJ, Kee SY, Lee J, Sohn JW, Kim MJ, et al. Disease spectrum of cervical lymphadenitis: analysis based on ultrasoundguided core-needle gun biopsy. J Infect 2007;55(4):310-6.

13) Balikci HH, Gurdal MM, Ozkul MH, Karakas M, Uvacin O, Kara N, et al. Neck masses: diagnostic analysis of 630 cases in Turkish population. Eur Arch Otorhinolaryngol 2013;270(11):2953-8.

14) Iguchi $H$, Wada $T$, Matsushita $N$, Teranishi $Y$, Yamane H. Clinical analysis of 21 cases of cervical tuberculous lymphadenitis without active pulmonary lesion. Acta Otolaryngol 2013;133(9):977-83. 